\title{
PUZZLE MEMPENGARUHI PERKEMBANGAN MOTORIK HALUS ANAK USIA PRASEKOLAH DI TK AT TAQWA MEKARSARI CIMAHI
}

\author{
Erni Yuniati \\ Departemen Keperawatan Akper Setih Setio, Muara Bungo, 37211 Indonesia \\ Email: e_yuniati@yahoo.com
}

\begin{abstract}
Abstrak
Menurut WHO, 5-25\% anak usia prasekolah mengalami gangguan perkembangan motorik halus. Perkembangan motorik halus anak salah satunya dipengaruhi oleh penggunaan alat permainan edukatif. Terdapat jenis permainan edukatif yang digunakan dalam menstimulus perkembangan motorik halus anak diantaranya adalah puzzle. Namun sayangnya dilapangan, kegiatan yang dapat menstimulus perkembangan motorik halus anak masih belum dilakukan dengan adekuat, dalam hal ini frekuensinya masih kurang dari yang digunakan. Sehingga perkembangan motorik halus anak menjadi kurang optimal. Tujuan penelitian ini untuk mengetahui pengaruh penggunaan alat permainan edukatif jenis puzzle terhadap perkembangan motorik halus anak usia prasekolah di Taman Kanak-Kanak at Taqwa Mekarsari, Cimahi Jawa Barat. Penelitian ini menggunakan metode penelitian quasi experiment design dengan rancangan pretest dan posttest. Teknik pengambilan sampel menggunakan purposive sampling sejumlah 17 responden kelompok intervensi permainan edukatif jenis puzzle. Cara pengumpulan data menggunakan kuisioner dan dengan cara observasi. Penilaian menggunakan lembar instrumen DENVER II yang diambil aspek pengukuran motorik halus. Analisa data yang digunakan adalah uji t 2 sampel dependen dan uji t 2 sampel independen untuk bivariat. Hasil penelitian membuktikan bahwa terdapat pengaruh intervensi permainan edukatif jenis puzzle terhadap perkembangan motorik halus anak usia prasekolah. Berdasarkan hasil penelitian, untuk menstimulus perkembangan motorik halus anak, agar dilakukan dengan menambah frekuensi permainan, dapat menggunakan puzzle.
\end{abstract}

Kata kunci: Perkembangan motoric halus, stimulus puzzle.

\begin{abstract}
According to WHO, 5-25\% of preschool aged children experience impaired smooth motor development. Fine motor development of the child one of them influenced by the use of educational game tools. There are types of educational games used in stimulating the smooth motor development of children such as puzzles. But unfortunately in the field, activities that can stimulate the smooth motor development of children are still not done adequately, in this case the frequency is still less than that used. So the smooth motor development of the child becomes less than optimal. The purpose of this study to determine the effect of the use of educational games type of puzzle to the fine motor development of preschoolers in Kindergarten at Taqwa Mekarsari, Cimahi West Java. This research uses quasi experiment design method with pretest and posttest design. The sampling technique used purposive sampling of 17 respondents of intervention group game of educational type of puzzle. Methods of data collection using questionnaires and by observation. Assessment using the DENVER II instrument sheet taken on the fine motor measurement aspect. Data analysis used is t test of 2 dependent samples and test 2 independent samples for bivariate. The results of this study show that there is an influence of educational game intervention type puzzle to the fine motor development of preschoolers. Based on the results of research, to stimulate the smooth motor development of children, to be done by increasing the frequency of the game, can use the puzzle.
\end{abstract}

Keywords: Development of fine motoric, puzzle stimulus 


\section{PENDAHULUAN}

Seorang anak dapat mengalami keterlambatan perkembangan pada hanya satu ranah perkembangan saja, tetapi dapat pula di lebih dari satu ranah perkembangan. Masalah ranah perkembangan yang sering terjadi pada anak usia dini/ prasekolah adalah perkembangan motorik halus (Ikatan Dokter Anak Indonesia, 2013). Dampak yang terjadi apabila kurangnya pencegahan gangguan perkembangan motorik halus pada anak akan menyebabkan perkembangannya tidak sesuai dengan umur, misalnya pada anak prasekolah seharusnya sudah mampu dalam hal motorik halus tetapi jika ada penyimpangan anak hanya mampu untuk melaksanakan tahap perkembangan motorik halus dibawah usia perkembangannya (Sa'amah, 2012). Sebagai contoh pada anak usia prasekolah anak belum mampu melakukan tugas perkembangan sesuai dengan usianya yaitu memegang krayon dengan benar. Solusi yang dapat dilakukan untuk mencegah terjadinya gangguan perkembangan motorik halus pada anak yaitu dengan melakukan deteksi dini tumbuh kembang anak dan skrining serta orang tua memberikan stimulasi lebih awal (Sa'amah, 2012).

Motorik halus merupakan aspek yang berhubungan dengan kemampuan anak untuk mengamati sesuatu. Motorik halus merupakan kegiatan melakukan gerakan yang melibatkan bagian-bagian tubuh tertentu saja dan dilakukan otot-otot kecil, tetapi memerlukan koordinasi yang cermat. Misalnya kemampuan untuk menggambar dan memegang sesuatu benda (Wong, 2009).

World Health Organizations (WHO, 2009), melaporkan bahwa 5-25\% dari anak-anak usia prasekolah menderita disfungsi otak minor, termasuk gangguan perkembangan motorik halus (Widati, 2012). Sedangkan berdasarkan data dari Depkes RI (2006) menunjukkan bahwa 0,4 juta atau sekitar $16 \%$ usia prasekolah di Indonesia mengalami gangguan perkembangan. Hal ini terjadi dipicu oleh kurangnya deteksi dini dan kurangnya stimulasi yang diberikan untuk mendukung perkembangan motorik halus.

Anak usia prasekolah adalah anak usia 3-6 tahun yang belum menempuh sekolah dasar (Depkes, 2010). Pendapat lain mengemukakan bahwa usia 4-6 tahun disebut dengan anak usia prasekolah yang merupakan bagian dari anak usia dini yang berada pada rentang usia lahir sampai 6 tahun dan fase ini merupakan usia emas (golden age).

Untuk mengetahui tahap perkembangan anak diperlukan deteksi dini tumbuh kembang (DDTK). Deteksi dini pada anak prasekolah dilakukan dengan menggunakan Kuisioner Pra Skrining Perkembangan (KPSP)/ DDST. KPSP/ DDST dapat dilakukan oleh tenaga kesehatan (Dokter, Bidan dan Perawat) sesuai dengan standar yang ada (Depkes RI, 2010).

Faktor yang mempengaruhi perkembangan anak usia prasekolah salah satunya adalah bermain. Bermain adalah cara yang paling berharga, melalui bermain, anak akan menggunakan sensor motorik atau fungsionalnya (Wong, 2009).

Puzzle merupakan salah satu bentuk permainan yang mampu mengasah kemampuan berpikir, mempermudah anak dalam mengingat dan memahami konsepkonsep, anak menjadi lebih kreatif dan manfaat bermain puzzle lainnya adalah berdampak pada perkembangan kognitif anak. Dalam bermain puzzle, anak dituntut bernalar sehingga otak anak akan terasah.

Hasil penelitian Medirisa et all (2015), tentang Pengaruh Pemberian Stimulus Bermain Puzzle Terhadap Perkembangan Motorik Halus Anak Usia 4-6 Tahun Di Taman Kanak-Kanak Aisyiyah Krasak, Teras, Boyolali, menunjukkan bahwa ada pengaruh permainan edukatif puzzle terhadap perkembangan motorik halus anak. Penelitian dilakukan selama 6 minggu $(1,5$ bulan). Teknik pengambilan sampel 
penelitian ini yaitu purpossive sampling dengan jumlah sampel yaitu 15 orang.

Fenomena saat ini, pada tahun pertama, sering kali tenaga kesehatan dan orang tua lebih memfokuskan pada perkembangan motorik kasar saja (Ardana et al, 2015). Hal ini menyebabkan perkembangan motorik yang dianggap normal tersebut dengan suatu harapan yang semu terhadap kemampuan intelektual anak. Padahal perkembangan motorik halus merupakan indikator yang lebih baik (lebih dapat menilai kemampuan motorik anak) daripada motorik kasar, dalam diagnosis gangguan motorik pada anak (Ardana et al, 2015).

Taman Kanak-Kanak (TK) At Taqwa, dari jumlah anak yaitu 85 orang, terdapat sekitar $40 \%$ anak belum dapat melaksanakan tugas perkembangan sesuai dengan usianya pada aspek motorik halus.

Masih terdapatnya data dan hambatan tersebut, perlu dilakukan pengembangan terhadap kemampuan motorik halus anak agar memiliki kemampuan motorik halus yang lebih baik. Berdasarkan latar belakang di atas, maka rumusan masalah dalam penelitian ini adalah Pengaruh Penggunaan Alat Permainan Edukatif Jenis Puzzle Terhadap Perkembangan Motorik Halus Anak Usia Prasekolah Di taman Kanak-Kanak At Taqwa Mekarsari, Cimahi Jawa Barat.

Tujuan penelitian ini adalah untuk mengetahui pengaruh penggunaan alat permainan edukatif jenis puzzle terhadap perkembangan motoric halus anak usia praskekolah. di Taman Kanak-Kanak at Taqwa Mekarsari, Cimahi Jawa Barat.

Manfaat penelitian bagi profesi keperawatan dapat dijadikan alternative untuk menerapkan permainan edukatif, bagi peneliti selanjutnya untuk pengembangan riset dapat digunakan dalam pelaksanaan asuhan keperawatan pada anak dalam mengatasi masalah perkembangan motoric halus anak, bagi guru TK dan bagi orang tua dapat dijadikan salah satu stimulasi yang bisa diterapkan ke anak dalam menstimulasi perkembangan motoric halus anak.

\section{METODE}

Penelitian ini menggunakan rancangan penelitian quasi eksperimen dengan menggunakan desain pretest dan posttest. Untuk mengukur pretest dan posttest menggunakan uji t dimana uji t 2 sampel dependen digunakan untuk melihat apakah ada pengaruh pretest dan posttest pada kelompok intervensi yang diberikan permainan puzzle.

Populasi pada penelitian ini adalah anak usia prasekolah TK At Taqwa Mekarsari Cimahi berjumlah 85 orang. Teknik pengambilan sampel dalam penelitian ini menggunakan Purpossive sampling yaitu metode pemilihan sampel yang dilakukan berdasarkan maksud atau tujuan tertentu yang ditentukan oleh peneliti. Sampel dalam penelitian ini adalah anak prasekolah di TK At Taqwa dengan kriteria inklusi. Berdasarkan perhitungan sampel minimal menurut Sugiyono (2012) dan berdasarkan perhitungan rumus sampel maka didapatkan sampel yaitu 17 orang diberikan perlakuan permainan puzzle. Penelitian dilakukan selama 1 (satu) bulan, penilaian menggunakan lembar kuisioner biodata anak usia prasekolah, lembar/ instrumen untuk melihat perkembangan motorik halus anak prasekolah (modifikasi dari Denver II aspek motorik halus) dan prosedur penggunaan alat permainan edukatif puzzle. Analisa data yang digunakan adalah analisa univariat dan bivariate dengan uji t-test.

\section{HASIL PENELITIAN}

Rerata perkembangan motorik halus anak sebelum dan setelah diberikan permainan edukatif jenis puzzle 
Tabel 1.1. Rerata perkembangan motorik halus anak sebelum dan setelah diberikan permainan edukatif jenis puzzle

\begin{tabular}{|c|c|c|c|c|}
\hline Variabel & Mean & SD & $\begin{array}{l}\text { Minimal- } \\
\text { Maksimal }\end{array}$ & 95\% CI \\
\hline & & & & \\
\hline Pretest & 3,35 & 0,493 & $3-4$ & $3,10-3,61$ \\
\hline Posttest & 1,88 & 0,600 & $1-3$ & $1,57-2,19$ \\
\hline
\end{tabular}

Berdasarkan tabel 1.1 dengan memperhatikan hasil distribusi nilai pada pretest intervensi permainan edukatif jenis puzzle didapatkan rata-rata pretest 3,35 , (95\% CI $=3,10-3,61)$ dengan SD 0,493, nilai skor terendah 3 dan tertinggi 4 . Dari hasil estimasi interval disimpulkan bahwa 95\% diyakini bahwa rata-rata pretest perkembangan motorik halus anak dengan kelompok intervensi permainan edukatif puzzle adalah antara 3,10 sampai dengan 3,61. Sedangkan hasil distribusi nilai pada posttest setelah intervensi permainan edukatif jenis puzzle didapatkan rata-rata $1,88,(95 \% \mathrm{CI}=1,57-2,19)$ dengan $\mathrm{SD}$ 0,600 , nilai skor terendah 1 dan tertinggi 3 . Dari hasil estimasi interval disimpulkan bahwa 95\% diyakini bahwa rata-rata posttest perkembangan motorik halus anak dengan kelompok intervensi permainan edukatif puzzle adalah antara 1,57 sampai dengan 2,19. Dari hasil estimasi interval disimpulkan bahwa 95\% diyakini bahwa selisih rerata peningkatan perkembangan motorik halus anak sebelum dan setelah intervensi permainan edukatif jenis puzzle adalah antara 1,53 sampai dengan 1,42.

Analisis pengaruh penggunaan alat permainan edukatif jenis puzzle terhadap perkembangan motorik halus anak usia prasekolah

Tabel 2.1. Hasil analisis pengaruh penggunaan alat permainan edukatif jenis puzzle terhadap perkembangan motorik halus.

\begin{tabular}{|c|c|c|c|c|c|}
\hline Variabel & Mean & SD & SE & P value & N \\
\hline Pretest & 3,35 & 0,493 & 0,119 & 0,0001 & 17 \\
\hline Posttest & 1,88 & 0,600 & 0,146 & 0,0001 & 17 \\
\hline
\end{tabular}

Berdasarkan tabel 2.1 menunjukkan bahwa rata-rata perkembangan motorik halus sebelum dilakukan permainan edukatif jenis puzzle atau pretest adalah 3,35 dengan standar deviasi 0,493. Setelah dilakukan permainan edukatif jenis puzzle atau posttest, didapatkan rata-rata perkembangan motorik halus adalah 1,88 dengan standar deviasi 0,600. Terlihat bahwa mean perbedaan antara pretest dan posttest adalah 1,47 dengan standar deviasi 0,624 . Hasil uji statistik didapatkan nilai $\mathrm{p}$ $=0,0001$ maka dapat disimpulkan ada perbedaan yang signifikan rata-rata motorik halus sebelum dan setelah dilakukan permainan edukatif jenis puzzle.

\section{PEMBAHASAN}

Rerata perkembangan motorik halus anak sebelum dan setelah dilakukan permainan edukatif jenis puzzle.

Dari hasil penelitian didapatkan hasil bahwa pada kelompok intervensi puzzle sebelum diberikan intervensi permainan edukatif jenis puzzle yaitu dengan nilai rata-rata 3,35. Sedangkan setelah diberikan intervensi permainan edukatif jenis puzzle didapatkan nilai rata-rata yaitu 1,88 . Dari hasil estimasi interval disimpulkan bahwa 95\% diyakini rerata perubahan perkembangan motorik halus anak sebelum intervensi permainan edukatif jenis puzzle berada diantara 3,10 sampai dengan 3,61. Kemudian dari hasil estimasi interval disimpulkan bahwa 95\% diyakini rerata perkembangan motorik halus anak setelah dilakukan intervensi jenis puzzle berada diantara 1,57 sampai dengan 2,19. Maka terlihat selisih rerata peningkatan perkembangan motorik halus sebelum dan setelah dilakukan intervensi permainan edukatif jenis puzzle yaitu antara 1,53 sampai dengan 1,42.

Dari hasil penelitian didapatkan hasil bahwa 17 orang kelompok intervensi puzzle terdiri dari 6 orang laki-laki dan 11 orang perempuan, didapatkan bahwa sebagian besar anak sebelum diberikan permainan edukatif jenis puzzle, motorik 
halusnya sedang yaitu 11 responden $(64,7 \%)$, selebihnya adalah $6(35,3 \%)$ responden memiliki perkembangan motorik halus rendah. Kemudian setelah dilakukan intervensi permainan edukatif jenis puzzle didapatkan bahwa sebagian besar anak motorik halusnya dalam kriteria tinggi yaitu $11(64,7 \%)$ responden, kemudian anak dengan perkembangan motorik halus sangat tinggi yaitu $4(23,5)$ responden dan selebihnya adalah 2 $(11,8 \%) \quad$ responden memiliki perkembangan motorik halus sedang.

Berdasarkan teori menurut Patmonodewo (2015), yang menyatakan bahwa media puzzle merupakan media sederhana yang dimainkan dengan bongkar pasang. Puzzle adalah salah satu bentuk permainan yang sangat dipercaya sebagai media yang bisa membantu mengembangkan kecakapan motorik halus dan dengan koordinasi antara tangan dan mata, menata puzzle menjadi sebuah bentuk hewan, pesawat, kapal dan sebagainya. Puzzle merupakan salah satu jenis alat permainan edukatif yang menarik untuk diperkenalkan pada anak TK.

Sejalan dengan hasil penelitian ini, bahwa bermain puzzle dapat menstimulasi atau meningkatkan kemampuan motorik halus anak. Bermain puzzle merupakan kegiatan anak melakukan permainan bongkar pasang, menyusun kotak-kotak, menyusun kepingan-kepingan hingga membentuk suatu pola tertentu. Dalam menyusun kepingan-kepingan puzzle melibatkan atau berhubungan dengan otototot kecil anak, terutama tangan dan jarijari tangan. Melalui aktivitas bermain puzzle, tanpa disadari anak akan belajar secara aktif untuk menggunakan jari-jari tangannya untuk menyusun gambar yang tepat dan hal tersebut tanpa disadari dapat melatih koordinasi mata dan tangan dengan baik sehingga dapat menstimulasi kemampuan motorik halus anak.

Hasil penelitian ini sejalan dengan hasil penelitian Pramono (2008) tentang efektifitas alat permainan edukatif jenis puzzle terhadap perkembangan motorik halus pada anak usia 4-5 tahun menyatakan bahwa terdapat pengaruh permainan edukatif puzzle terhadap motorik halus anak usia 4-5 tahun

Hasil penelitian ini juga didukung oleh Hidayat (2007) penggunaan media puzzle pada anak usia prasekolah sangat bagus dan sesuai dengan usia anak. Media puzzle sangat sering digunakan di Taman Kanak-Kanak karena media puzzle adalah salah satu bentuk permainan yang memiiki nilai-nilai edukatif. Dalam bermain puzzle membutuhkan ketelitian, anak akan dilatih untuk memusatkan pikiran, karena anak harus berkonsentrasi ketika menyusun kepingan-kepingan puzzle tersebut hingga menjadi sebuah gambar yang utuh dan lengkap. Dengan bermain puzzle, anak belajar memahami konsep bentuk, warna, ukuran dan jumlah. Tentunya bentuk puzzle yang digunakan lebih beragam dan mempunyai warna yang lebih mencolok. Memasang kepingan puzzle berarti mengingat gambar utuh, kemudian menyusun komponennya menjadi sebuah gambar benda.

Berdasarkan uraian diatas dapat diartikan bahwa bermain puzzle merupakan media bermain sederhana yang dimainkan secara bongkar pasang yang membutuhkan ketelitian, karena anak dilatih untuk dapat memusatkan pikiran agar dapat berkonsentrasi, selain itu dengan bermain puzzle anak belajar tentang konsep bentuk, warna, ukuran dan jumlah yang dapat membantu mengembangkan kemampuan motorik halus anak dengan melibatkan koordinasi mata dan tangan serta melatih otot-otot jari tangan.

Sejalan dengan penelitian Niko dan Mulyani (2013) menjelaskan bahwa puzzle merupakan media visual yaitu merupakan media yang menyampaikan pesannya melalui proses melihat. Kemampuan memahami pesan media visual itu tergantung keterampilan seseorang dalam menyampaikan dan menerima pesan visual. 
Hasil penelitian ini didukung dengan penelitian Wahyuni dan Maureen (2010) menyebutkan bahwa media puzzle adalah alat yang digunakan untuk menyalurkan pesan dengan cara menyambungkan bagian satu dengan yang lainnya sehingga membentuk suatu gambar. Media puzzle adalah media visual dua dimensi yang mempunyai kemampuan untuk menyampaikan informasi secara visual tentang segala sesuatu sebagai pindahan dari wujud yang sebenarnya. Didukung oleh penelitian Chaiyunah (2006) menjelaskan bahwa ada hubungan yang signifikan antara pemanfaatan media puzzle dengan kreatifitas berfikir anak, dan pemanfaatan puzzle jika dilaksanakan dengan baik akan dapat meningkatkan kemampuan berfikir anak terutama dalam pengenalan bentuk

\section{Pengaruh penggunaan alat permainan edukatif jenis puzzle terhadap perkembangan motorik halus anak}

Dari hasil penelitian didapatkan hasil bahwa rata-rata perkembangan motorik halus sebelum dilakukan permainan edukatif jenis puzzle adalah 3,35. Setelah dilakukan permainan edukatif jenis puzzle, didapatkan rata-rata perkembangan motorik halus adalah 1,88. Terlihat bahwa mean perbedaan antara sebelum dan setelah dilakukan intervensi permainan edukatif jenis puzzle adalah 1,47. Hasil uji statistik didapatkan nilai $\mathrm{p}=0,0001$ maka dapat disimpulkan ada perbedaan yang signifikan rata-rata motorik halus sebelum dan setelah dilakukan permainan edukatif jenis puzzle.

Berdasarkan penelitian Medirisa (2015), menyatakan bahwa permainan puzzle dapat menstimulus perkembangan motorik halus anak dimana tindakan puzzle dapat melatih kerja jari-jemari anak yang dikoordinasikan dengan kerja otak dalam menyusun kepingan-kepingan, sehingga anak menjadi terlatih dan secara tidak langsung hal ini meningkatkan kemampuan motorik halus anak.
Sejalan dengan hasil penelitian ini bahwa terlihat terjadi peningkatan perkembangan motorik halus anak dari yang sebelum dilakukan intervensi permainan puzzle, menjadi meningkat setelah diberikan permainan puzzle. Dalam bermain puzzle adalah permainan yang terdiri dari potongan gambar-gambar, kotak-kotak, huruf-huruf atau angka-angka yang disusun seperti dalam sebuah permainan yang akhirnya membentuk sebuah pola tertentu sehingga membuat peserta didik menjadi termotivasi untuk menyelesaikan puzzle secara tepat melalui media visual dimana permainan tersebut melibatkan kerjasama/ koordinasi mata dan tangan, syaraf taktil anak, otot-otot kecil dan jari jemari tangan anak yang tanpa disadari dapat menstimulasi kemampuan motorik halus anak.

Hasil penelitian ini didukung oleh Yustisia (2013), menjelaskan bahwa puzzle dapat meningkatkan keterampilan motorik halus merupakan kemampuan yang berhubungan dengan otot-otot kecil, terutama tangan dan jari-jari tangan dan melatih koordinasi mata dan tangan. Melalui aktivitas bermain puzzle, tanpa disadari anak akan belajar secara aktif untuk menggunakan jari-jari tangannya untuk menyusun gambar yang tepat.

Hasil penelitian ini juga selaras dengan penelitian Medirisa, Susilo dan Aniroh (2015) yang menjelaskan bahwa terdapat pengaruh bermain puzzle terhadap perkembangan motorik halus anak. Hal ini dikarenakan permainan puzzle merupakan salah satu bentuk stimulus dan ketika diberi stimulus permainan puzzle anak tersebut memperhatikan sehingga dapat melatih kerja jari-jemari anak yang dikoordinasikan dengan kerja otak dalam menyusun kepingan-kepingan, sehingga anak menjadi terlatih dan secara tidak langsung hal ini dapat meningkatkan kemampuan motorik halus anak.

Hasil penelitian ini sejalan dengan penelitian Setyaningsih (2014), tentang pengaruh penggunaan alat permainan edukatif jenis puzzle terhadap 
perkembangan anak usia prasekolah di Taman Kanak-Kanak Aisyiyah Pertanahan Kebumen, Jawa Tengah, menunjukkan bahwa ada pengaruh permainan edukatif puzzle terhadap perkembangan anak usia prasekolah

Sejalan dengan penelitian Indahwati, Sunarno dan Sajidan (2012), menyatakan bahwa puzzle merupakan teknik pembelajaran yang memiliki keunggulan dapat menjadikan siswa/ anak senang dan lebih bersemangat. Dalam penelitiannya juga menjelaskan bahwa siswa/ anak yang mempunyai aktivitas belajar rendah kemampuan memori tinggi akan memperoleh prestasi kognitif lebih besar jika diajar/ diberikan permainan dengan teknik puzzle. Sebaliknya juga bisa terjadi siswa yang memiliki aktivitas belajar tinggi kemampuan memori rendah akan memperoleh prestasi kognitif lebih besar jika diajar/ diberikan permainan dengan teknik puzzle.

Hasil penelitian ini didukung dengan penelitian Syafitri, Syukri dan Yuniarni (2014) menyatakan bahwa permainan puzzle dapat meningkatkan kemampuan daya ingat pada anak usia 5-6 tahun di Taman Kanak-Kanak Pertiwi Kendawangan, Pontianak. Hal ini dikarenakan media puzzle terdiri dari bermacam warna dan bentuk pola dapat menarik perhatian anak. Cara menggunakannya dengan menyusun kepingan puzzle dalam suatu pola sesuai dengan urutan gambar. Pada pelaksanaan permainan melibatkan anak secara langsung, sehingga anak yang melakukan kegiatan bermain tersebut secara berkelompok untuk mencari gambar yang sesuai dengan instruksi yang diberikan. Dengan kegiatan tersebut, dapat meningkatkan kemampuan daya ingat anak dengan cara yang menyenangkan. Manfaat bermain puzzle adalah diantaranya meningkatkan keterampilan motorik halus berkaitan dengan kemampuan anak menggunakan otot-otot kecilnya khususnya tangan dan jari-jari tangan. Puzzle dapat dimainkan secara perorangan maupun secara berkelompok (Syafitri, Syukri \& Yuniarni, 2014). Permainan yang dilakukan oleh anak-anak secara kelompok akan meningkatkan interaksi sosial anak. Jika anak bermain puzzle dirumah orangtua dapat menemani anak untuk berdiskusi menyelesaikan puzzlenya, tetapi hanya sebatas memberikan arahan kepada anak dan tidak terlibat secara aktif membantu anak menyusun puzzle. Puzzle dapat melatih koordinasi tangan dan mata anak untuk mencocokkan keping-keping puzzle dan menyusunnya menjadi satu gambar. Puzzle juga membantu anak mengenal dan menghafal bentuk. Bermain puzzle membutuhkan ketekunan, kesabaran dan memerlukan waktu untuk berfikir dalam menyelesaikan tantangan (Syafitri, syukri \& Yuniarni, 2014).

\section{KESIMPULAN}

1. Rerata perkembangan motorik halus anak sebelum dan setelah diberikan permainan edukatif jenis puzzle terjadi peningkatan perkembangan motorik halus yang signifikan terlihat adanya peningkatan rata-rata kemampuan motorik halus anak, dilihat dari nilai rata-rata sebelum diberikan permainan edukatif jenis puzzle yaitu 3,35 menjadi meningkat setelah diberikan permainan edukatif jenis puzzle yaitu 1,88.

2. Pengaruh penggunaan alat permainan edukatif jenis puzzle terhadap perkembangan motorik halus sebelum dan sesudah penggunaan alat permainan edukatif jenis puzzle terhadap perkembangan motorik halus, dilihat dari nilai pretest-posttest nilai pvaluenya $=0,0001$, maka dapat disimpulkan bahwa ada perbedaan yang signifikan rata-rata pretest dan posttest yaitu terjadi perubahan peningkatan perkembangan motorik halus anak setelah diberikan intervensi permainan edukatif jenis puzzle. 


\section{DAFTAR PUSTAKA}

Abdullah, M. (2015). Metodologi penelitian kuantitatif. Yogyakarta: Aswaja Pressindo Anggota IKAPI.

Adriana, D. (2011). Tumbuh kembang \& terapi bermain pada anak. Jakarta: Salemba Medika.

Alligood, M,R. (2014). Nursing theorists and their work, eighth edition. Louis: Mosby Elsevier, Inc.

Andika, M. Meningkatkan kemampuan memahami wacana melalui media pembelajaran puzzle.

Arikunto, S. (2013). Prosedur penelitian. Jakarta: PT. Rineka Cipta.

Astuti, E.S., Wahyuningsri., dan Wirastuti, W. (2012). Pengaruh stimulasi motorik halus terhadap daya konsentrasi belajar anak usia prasekolah. Malang.

Betz, C.L., dan Sowden, L.A. (2009). Keperawatan pediatri (Mosby's pediatric nursing reference). Jakarta: EGC.

Christiana., Wicandra, O.B., dan Asthararianty. Perancangan media edukasi buku cross stitch untuk meningkatkan motorik halus pada anak. Universitas Kristen Petra, Surabaya.

Dharma, K.K. (2011). Metode penelitian keperawatan : panduan melaksanakan dan menerapkan hasil penelitian. Jakarta: Trans Info Media.

Dahlan, S. (2013). Besar sampel dan cara pengambilan sampel dalam penelitian kedokteran dan kesehatan. Jakarta: Salemba Medika.

Dahlan, S. (2009). Langkah-langkah membuat proposal penelitian bidang kedokteran dan kesehatan. CV. Sagung Seto.

Dahlan, S. (2013). Statistik untuk kedokteran dan kesehatan. Jakarta: Salemba Medika.

Dariyo, A. (2007). Psikologi perkembangan. Bandung: Refika Aditama.
Dewi, W.S. (2015). Penerapan model pembelajaran Number Heads Together (NHT) berbantuan media puzzle untuk meningkatkan perkembangan kognitif anak kelompok B2 TK Kemala Bhayangkari 1 Denpasar, $\mu 712$.

Dinkes Cimahi. (2016). Data penyimpangan tumbuh kembang Kota Cimahi.

Handayani, R.D. dan Puspitasari, P.D. (2008). Pengaruh terapi bermain terhadap tingkat kooperatif selama menjalani perawatan pada anak usia prasekolah (3-5 tahun) di Rumah Sakit Panti Rapih Yogyakarta. Jurnal keshatan Surya Medika Yogyakarta.

Hidayat, A.A. (2005). Pengantar ilmu keperawatan anak 1. Jakarta: Salemba Medika.

Indahwati, J., Sunarno, W., dan Sajidan. (2012). Penerapan model inquiry training melalui teknik peta konsep dan teknik puzzle ditinjau dari tingkat keberagaman aktivitas belajar dan kemampuan memori. 1 (2).

Jamaris, M. (2006). Perkembangan dan pengembangan anak usia Taman Kanak-Kanak. Jakarta: Anggota IKAPI.

Kementrian Kesehatan R.I. (2010). Pedoman pelaksanaan stimulasi, deteksi dan intervensi dini tumbuh kembang anak di tingkat pelayanan kesehatan dasar. Indonesia Sehat 2010, Bakti Husada.

Khasanah, I., Prsetyo, A., dan Rakhmawati, E. (2011). Permainan tradisional sebagai media stimulasi aspek perkembangan anak usia dini. Jurnal Penelitian PAUDIA. 1 (1).

Lindawati. (2013). Faktor-faktor yang berhubungan dengan perkembangan motorik anak usia prasekolah. Jurnal Health Quality 4 (1). 
Madya, Y. Pengaruh media puzzle terhadap kemampuan anak dalam mengenal bentuk geometri di kelompok A TK qushrul ubudiyah Surabaya.

Medirisa, L.P., Susilo, D.J., dan Aniroh, U. (2015). Pengaruh pemberian stimulus permainan puzzle terhadap perkembangan motorik halus anak usia 4-6 tahun di Taman KanakKanak Aisyiyah Krasak, Teras, Boyolali.

Meilani, S., Sofia, A., dan Riswandi. (2015). Hubungan antara aktivitas bermain pembangunan dengan kemampuan motorik halus anak 56 tahun.

Nirmalasari, D., Mulyani, B., dan Utami, B. (2013). Studi komparasi penggunaan media mind map dan crossword puzzle pada metode proyek ditinjau dari kreativitas siswa terhadap prestasi belajar pada materi pokok system koloid kelas xi semester genap SMA N 1 Banyudono. 2 (4).

Niko, E., dan Mulyani. (2013). Penggunaan media puzzle untuk meningkatkan hasil belajar IPS dengan tema keluarga pada siswa sekolah dasar. 1 (2).

Nurs, N., Susilaningrum, R., dan Utami, S. (2008). Asuhan keperawatan bayi dan anak. Jakarta: Salemba Medika.

Papalia, D.E., Olds, S.W., dan Feldman, R.D. (2010). Human development (Perkembangan manusia edisi 10 buku 2), (penerjamah Brian Marwensdy). Jakarta: Salemba Humanika.

Pramono H. W. (2008). Efektifitas alat permainan edukatif puzzle terhadap perkembangan motorik halus pada anak usia 4 - 5 tahun.

Riyanto, A. (2011). Pengolahan dan analisis data kesehatan. Yogyakarta: Nuha Medika.
Safitri, D., Syukri, M., dan Yuniarni, D. (2014). Peningkatan kemampuan daya ingat melalui permainan puzzle pada anak usia 5-6 tahun.

Sastrasmoro, S., dan Ismael S. (2011). Dasar-dasar metodologi penelitian Klinis. CV. Sagung Seto.

Soetjiningsih dan Ranuh, G. (2013). Tumbuh kembang anak. Jakarta: EGC.

Sugiyono. (2014). Statistik untuk penelitian. Bandung: Alfabeta CV.

Sujarweni, W. (2014). Metodologi penelitian keperawatan. Yogyakarta: Penerbit Gava Media.

Suriadi dan Yuliani, R. (2010). Asuhan keperawatan pada anak. Jakarta: CV. Sagung Seto.

Suwariyah, P. (2013). Test perkembangan bayil anak, menggunakan Denver Development Screening Test (DDST). Jakarta: CV. Trans Info Media.

Setyaningsih, S. (2014), Pengaruh penggunaan alat permainan edukatif jenis puzzle terhadap perkembangan anak usia prasekolah di Taman Kanak-Kanak Aisyiyah Pertanahan Kebumen, Jawa Tengah, Tesis, Jawa Tengah, Stikes Jenderal Achmad Yani.

Tomey, A.M. (2001). Teori ilmu keperawatan, para ahli dan berbagai pandangannya.

Usman, H., dan Akbar S.P. (2006). Pengantar statistik. Jakarta: PT. Bumi Aksara.

Wahyuningsri., Astuti, E.S., dan Rossyana. (2013). Pengembangan kemampuan motorik anak usia prasekolah melalui aktivitas bermain model skill play. Jurnal Ilmu Pendidikan, 19 (2).

Wahyuni, N., dan Maureen, Y. (2010). Pemanfaatan media puzzle metamorfosis dalam pembelajaran sains untuk meningkatkan hasil belajar siswa kelas II SDN Sawunggaling Surabaya. 1 (2). 
Wong, D. (2009). Buku ajar keperawatan pediatrik. Jakarta: EGC.

Wulandari, A., Putra, M., dan Suniasih, N. (2015). Penerapan metode demonstrasi berbantuan media bahan alam dengan teknik mencetak untuk meningkatkan perkembangan motorik halus pada anak kelompk B TK Ganesha denpasar. e-Journal PG-PAUD Universitas Pendidikan Ganesha Jurusan Pendidikan Guru Pendidikan Anak Usia Dini. 3 (1).

Yuniarti, S. (2015). Asuhan tumbuh kembang neonatus, bayi-balita dan anak prasekolah. Bandung: Refika Aditama.

Zaviera, F. (2008). Mengenal dan memahami tumbuh kembang anak. Jogjakarta: Katahati/ ISBN.

Zellawati, A. (2011). Terapi Bermain Untuk Mengatasi Permasalahan Pada Anak. 2 (3). 